\title{
From margarine to butter: predictors of changing bread spread in an 11 -year population follow-up
}

\author{
Ritva Prättälä ${ }^{1}$, Esko Levälahti ${ }^{1}$, Tea Lallukka ${ }^{2,3}$, Satu Männistö ${ }^{1}$, Laura Paalanen ${ }^{1}$, \\ Susanna Raulio ${ }^{1, *}$, Eva Roos ${ }^{3,4}$, Sakari Suominen ${ }^{4,5,6}$ and Tomi Mäki-Opas ${ }^{1}$ \\ ${ }^{1}$ National Institute for Health and Welfare, PO Box 30, Fl-00271 Helsinki, Finland: ${ }^{2}$ Finnish Institute of Occupational \\ Health, Helsinki, Finland: ${ }^{3}$ Department of Public Health, University of Helsinki, Helsinki, Finland: ${ }^{4}$ Folkhälsan \\ Research Center, Finland and Department of Public Health, University of Helsinki, Helsinki, Finland: ${ }^{5}$ Department of \\ Public Health, University of Turku, Turku, Finland: ${ }^{6}$ Department of Public Health, University of Skövde, Skövde, Sweden
}

Submitted 13 April 2015: Final revision received 5 October 2015: Accepted 2 November 2015: First published online 21 December 2015

\begin{abstract}
Objective: Finland is known for a sharp decrease in the intake of saturated fat and cardiovascular mortality. Since 2000, however, the consumption of butter-containing spreads - an important source of saturated fats - has increased. We examined social and health-related predictors of the increase among Finnish men and women.

Design: An 11-year population follow-up.

Setting: A representative random sample of adult Finns, invited to a health survey in 2000.

Subjects: Altogether 5414 persons aged 30-64 years at baseline in 2000 were re-invited in 2011. Of men 1529 (59\%) and of women 1853 (66 \%) answered the questions on bread spreads at both time points. Respondents reported the use of bread spreads by choosing one of the following alternatives: no fat, soft margarine, butter-vegetable oil mixture and butter, which were later categorized into margarine/no spread and butter/butter-vegetable oil mixture (= butter). The predictors included gender, age, marital status, education, employment status, place of residence, health behaviours, BMI and health. Multinomial regression models were fitted.

Results: Of the 2582 baseline margarine/no spread users, $24.6 \%$ shifted to butter. Only a few of the baseline sociodemographic or health-related determinants predicted the change. Finnish women were more likely to change to butter than men. Living with a spouse predicted the change among men.

Conclusions: The change from margarine to butter between 2000 and 2011 seemed not to be a matter of compliance with official nutrition recommendations. Further longitudinal studies on social, behavioural and motivational predictors of dietary changes are needed.
\end{abstract}

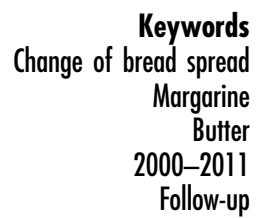

Finland is known for its successful health policies to reduce CVD. Since the late 1960s cardiovascular mortality and serum cholesterol levels have decreased remarkably ${ }^{(1,2)}$. The decrease in serum cholesterol can mainly be explained by changes in dietary fats. The proportion of saturated fat in the total energy intake has decreased ${ }^{(3,4)}$ and the consumption of bread spreads has changed accordingly. In the late 1970 s over $60 \%$ of Finns used butter on bread ${ }^{(5)}$. In 2000 only $6 \%$ used butter while butter-vegetable oil mixture was used by $17 \%{ }^{(6)}$. The changes have been interpreted as examples of successful food and nutrition policies and dietary interventions ${ }^{(7,8)}$.

Based on the Finnish Food Balance Sheets, butter consumption began to increase in 2005 after a steady decrease previously ${ }^{(9)}$. The changing trend in consumption of butter-containing fats was also revealed by cross-sectional surveys ${ }^{(10)}$. The percentage contribution to total energy intake (E\%) from fat increased between 2007 and 2012, from 33 to $36 \mathrm{E} \%$ among men and from 31 to $36 \mathrm{E} \%$ among women. The intake of saturated fat increased from 14 to 15 $\mathrm{E} \%$ among men and from 13 to $15 \mathrm{E} \%$ among women. Serum cholesterol levels increased congruently: among men from 5.25 to $5.34 \mathrm{mmol} / \mathrm{l}$ and among women from 5.15 to $5.31 \mathrm{mmol} / \mathrm{l}^{(11)}$. In 2012, more than $40 \%$ of saturated fat was obtained from dairy products. Among Finnish men aged 25-64 years, the most important sources of saturated fat were dishes prepared with meat or meat products (15\%), butter and butter-containing bread spreads (14\%) and 
cheese (13\%). Among men aged 65-74 years the share of butter and butter-containing spreads was $15 \%$. Finnish women obtained $14 \%$ of saturated fat from cheese, $12 \%$ from dishes prepared with meat or meat products, and $11 \%$ from butter and butter-containing spreads. Among women aged 65-74 years the share of butter and butter-containing spreads was $12 \%^{(12,13)}$

Finland is not the only Nordic country where the consumption of saturated fat sources has increased recently. According to the FAO Food Balance Sheets the domestic supply of butter has increased in all Nordic countries except Iceland between 2007 and 2011. The increase was sharper in Sweden and Finland than in Norway ${ }^{(14)}$. According to Icelandic cross-sectional surveys, the intake of saturated fat decreased especially between 1990 and 2002, while it changed less between 2000 and 2010/11 ${ }^{(15)}$. In Northern Sweden, the consumption of butter and butter-containing fats as bread spreads increased sharply between 2004/2005 and $2010^{(16)}$. The latest increases in the intake of saturated fat in Finland and Sweden have been associated with critical attitudes towards nutrition recommendations and supportive opinions for a low-carbohydrate diet in the mass media $^{(11,16,17)}$.

The contribution that diet makes to health and illness has been widely studied in representative and longitudinal population studies. In addition, dietary interventions aiming at specified changes have shed light on the determinants of dietary change. Social and other determinants of health behaviours have also been widely investigated. However, we are not aware of comparable longitudinal population studies analysing multiple social predictors - for instance gender, education, marital status - and health-related predictors of dietary change in representative samples of working-age populations, particularly regarding the recent changes in the use of bread spreads. Studies on the social determinants of favourable health behaviour change ${ }^{(18,19)}$ have applied the theoretical approaches of Rogers ${ }^{(20)}$ and Bourdieu $^{(21)}$. The two approaches lead to the assumption of higher social classes as pioneers of modern and healthier dietary practices. Bourdieu ${ }^{(21)}$ and Rogers ${ }^{(20)}$ paid no special attention to gender, although gender differences in dietary practices have been consistently demonstrated. According to a comparative study among university students from twenty European and three Asian countries ${ }^{(22)}$, 'women across the world are more convinced than men that dietary choices are important'. Women's stronger belief in the importance of healthy eating and their tendency for dieting contribute to gender differences in food choices. Four decades ago, Finns living in the countryside and having a low educational level more often used butter and high-fat milk than urban Finns with a high educational level ${ }^{(23)}$. Data collected in 1992 no longer showed socio-economic differences in butter consumption $^{(24)}$. Roos et al. ${ }^{(24)}$ classified butter as a traditional and unhealthy food. The higher socio-economic groups consumed more modern foods and the lower socio-economic groups more traditional foods. Finnish women already in the 1970 s more often used margarine and less often used butter than the men ${ }^{(23)}$. Women also had otherwise healthier food habits and the shift towards healthier food habits began earlier among women than men ${ }^{(25)}$.

Contradictory assumptions on changes in bread spreads between 2000 and 2011 can be presented. First, butter may have been taken up first by the lower socio-economic groups. In the 1970s, the low socio-economic groups preferred butter and the high socio-economic groups again preferred margarine; therefore, the previous butter users may have shifted more easily back to their earlier preference. Second, the high socio-economic groups were in the 1990s pioneers of modern foods. If they still take up new food habits first, they may have shifted from margarine to butter in the 2000s. Third, provided that women are consistently more motivated to follow dietary recommendations, they may maintain their habit of using margarine. Fourth, women who pay more attention to food choices than the men may have responded to the public critique on dietary recommendations and therefore have chosen butter, especially women in high socio-economic groups.

The goal of the present study was to examine the role of gender and socio-economic position (educational level, employment status), place of residence and marital status as predictors of the shift from butter alternatives (margarine/no spread) to butter-containing bread spreads in a cohort of Finns aged 30-64 years over an 11-year follow-up. Other health-related behaviours and health indicators were also included in the analyses as they are in many ways linked with food habits ${ }^{(26)}$.

\section{Methods}

The data originate from the Health 2000 and Health 2011 health examination studies ${ }^{(27)}$ carried out by the National Institute for Health and Welfare. All individuals who were invited to the Health 2000 study and were still living in Finland were re-invited eleven years later ${ }^{(28,29)}$. In 2000 and 2011, the participants went through a similar protocol: they were clinically examined, interviewed and given several questionnaires to be completed at home. The target group for this study were Finns aged 30-64 years at baseline. The baseline sample (2867 men and 2968 women, $n$ 5835) represents the concurrent Finnish population aged 30-64 years. The response rate at baseline was $86 \%$. Altogether 2596 men and 2818 women ( $n$ 5414) - respondents and non-respondents of Health 2000 - were invited to the follow-up in 2010. At follow-up, $21 \%$ (1260/5835) of those invited in 2000 could not be re-invited because they had declined further studies in 2000, had died, had moved abroad or had an unknown address (Fig. 1).

In total, 1529 (59\%) of the invited men and 1853 (66\%) of the invited women (together $62 \%$ of those invited to follow-up and $58 \%$ of the original baseline sample; Fig. 1) answered the questions concerning the use of butter, 


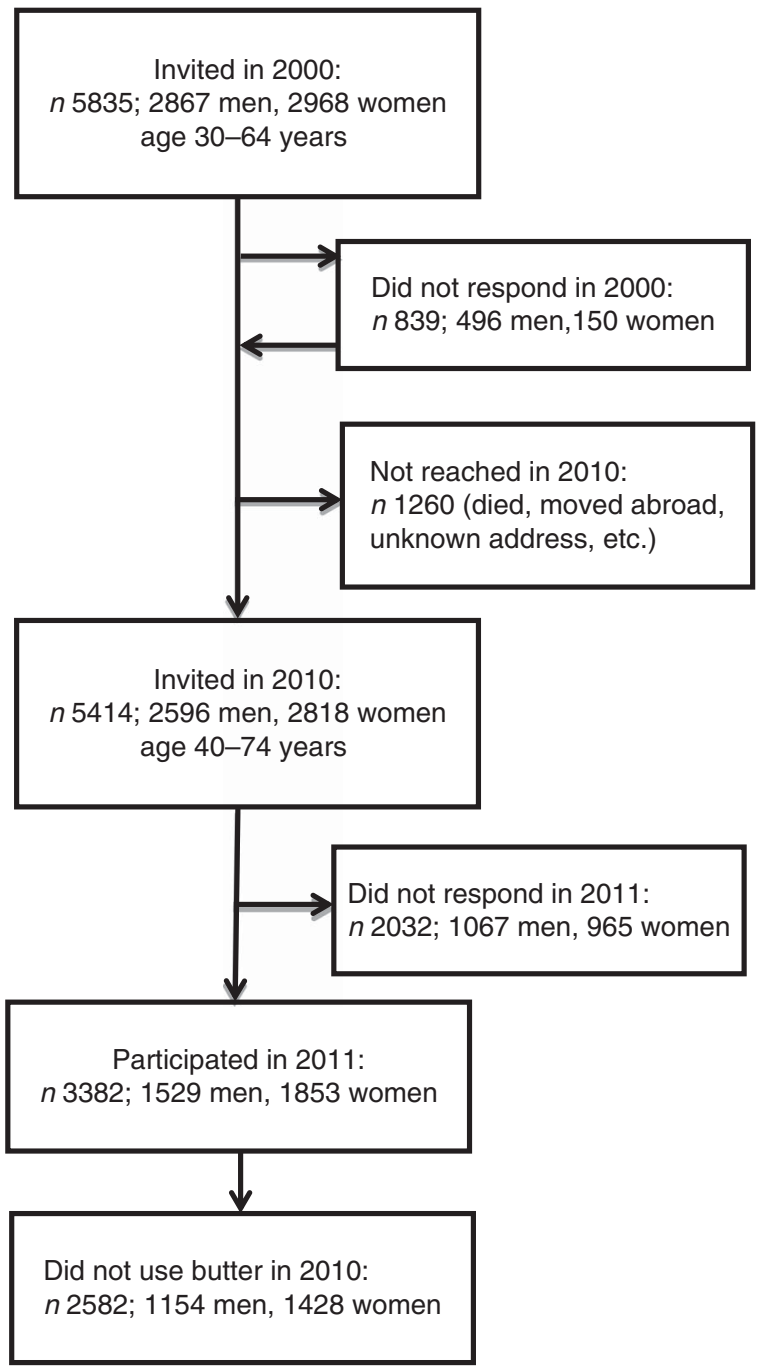

Fig. 1 Participation in the Health 2000 and Health 2011 surveys (Finnish men and women aged 30-64 years in 2000)

margarine and other bread spreads at both baseline and follow-up in 2011 (Table 1). This group was included in the analyses on bread spreads.

\section{Outcome variable}

The distribution of the respondents according to the studied variables is presented in Table 1 . The type of bread spread was assessed with one interview question in 2000 and 2011: 'What kind of fat do you mainly have on bread?' This question has been used in Finnish studies aiming to analyse trends and socio-economic variation in food habits ${ }^{(6,30)}$. The respondent could choose one from the following six alternatives: (i) no fat on bread; (ii) margarine/spread with less than $65 \%$ fat; (iii) plant stanol margarine, (iv) soft margarine/spread including $70-80 \%$ fat; (v) mixture of butter and vegetable oil; and (vi) butter. The six response alternatives were classified into two types: having 'butter or butter-vegetable oil mixture' on bread (responses $\mathrm{v}$ and vii) and having 'other alternatives' on bread (responses i-iv). There were two reasons for the rough binary classification and for the combined class of those who used margarines and those who did not use any spread on bread. First, the public debate in Finland has dealt especially with the increasing consumption of butter. Second, analysing predictors of changes between all spread types leads to too small cell sizes and loss of statistical power (Table 1).

As the study focused on predictors of the change from having margarine/no spread on bread to having butter-containing spread on bread, only those who did not use butter at baseline (belonged to the group of 'other alternatives', that is 1154 men and 1428 women, $n$ 2582) were included in the statistical models (Table 2, Fig. 1). In the following, the category of 'butter or butter-vegetable oil mixture' is called 'butter'.

\section{Predictor variables}

The variables included gender, educational level, employment, marital status and place of residence at baseline. The sociodemographic variables were chosen on the basis of previous theoretical approaches ${ }^{(20,21)}$ that have explained lifestyle changes in society. In addition, evidence obtained from studies on Finnish food consumption trends was taken into account ${ }^{(6,30)}$.

Age was divided into 10-year groups. In the final analyses the respondents were classified into two age groups: 30-44 years and 45-64 years. Respondents who were younger than 30 years or 65 years or older at baseline were excluded since we focused the analyses on those whose educational level was assumed to have stabilized and who were available for the labour market at baseline. Education was chosen as the indicator of socio-economic status. The variable on education was based on educational degrees and categorized into three levels: low (elementary school, vocational education or apprenticeship), middle (secondary education) and high (university, college, polytechnic, doctoral degree). Place of residence was categorized into larger cities with more than 100000 inhabitants and smaller municipalities, since there are only seven cities in Finland with a population number exceeding 100 000. The original five marital status categories were combined into two groups: married/cohabiting and those living alone (divorced or separated, widowed, single). Employment status was first classified as employed, unemployed, student/military conscript or civil servant/retired/other, but later combined into two categories, employed and not employed (Table 1).

In addition to the sociodemographic factors, other variables describing health behaviours and health-related factors likely to be associated with change in bread spreads were included in the analyses. Other health behaviours consisted of physical activity, smoking, alcohol consumption, and consumption of vegetables and rye bread. Leisure-time physical activity was asked in the questionnaire: 'How much do you exercise and strain 
Table 1 Characteristics of the study population* of Finnish men and women participating in the Health 2000 and Health 2011 surveys

\begin{tabular}{|c|c|c|c|c|c|}
\hline & \multicolumn{2}{|c|}{ Men } & \multicolumn{2}{|c|}{ Women } & \multirow[b]{2}{*}{$P$ value- } \\
\hline & $n$ & $\%$ & $n$ & $\%$ & \\
\hline \multicolumn{6}{|l|}{ Age (years), 2000} \\
\hline $30-44$ & 671 & 43.9 & 813 & 43.9 & \\
\hline $45-64$ & 858 & $56 \cdot 1$ & 1040 & $56 \cdot 1$ & \\
\hline \multicolumn{6}{|l|}{ Education, 2000} \\
\hline High & 467 & 30.5 & 799 & $43 \cdot 1$ & \\
\hline Middle & 650 & 42.5 & 580 & $31 \cdot 3$ & \\
\hline Low & 412 & 26.9 & 474 & $25 \cdot 6$ & $<0.001$ \\
\hline \multicolumn{6}{|l|}{ Population size, 2000} \\
\hline$<100000$ & 1105 & $72 \cdot 3$ & 1277 & 68.9 & \\
\hline$\geq 100000$ & 424 & $27 \cdot 7$ & 576 & $31 \cdot 1$ & $<0.05$ \\
\hline \multicolumn{6}{|l|}{ Marital status, 2000} \\
\hline Married or cohabiting & 1209 & $79 \cdot 1$ & 1400 & $75 \cdot 6$ & \\
\hline Divorced, widowed, single & 320 & $20 \cdot 9$ & 453 & 24.4 & $<0.05$ \\
\hline \multicolumn{6}{|l|}{ Main economic activity, 2000} \\
\hline Employed & 1209 & $79 \cdot 1$ & 1364 & 73.6 & \\
\hline Not employed & 320 & $20 \cdot 9$ & 489 & 26.4 & $<0.001$ \\
\hline \multicolumn{6}{|l|}{ Leisure-time physical activity, 2000} \\
\hline Active & 1138 & $76 \cdot 0$ & 1445 & $78 \cdot 7$ & \\
\hline Inactive & 359 & $24 \cdot 0$ & 391 & $21 \cdot 3$ & \\
\hline \multicolumn{6}{|l|}{ Smoking, 2000} \\
\hline Not daily & 1153 & 75.4 & 1518 & $82 \cdot 0$ & \\
\hline Daily & 376 & $24 \cdot 6$ & 334 & $18 \cdot 0$ & $<0.001$ \\
\hline \multicolumn{6}{|l|}{ Alcohol consumption, 2000} \\
\hline Lowest & 494 & 33.0 & 672 & 36.5 & \\
\hline Medium & 537 & $35 \cdot 8$ & 575 & 31.2 & \\
\hline Highest & 468 & $31 \cdot 2$ & 596 & $32 \cdot 3$ & $<0.001$ \\
\hline \multicolumn{6}{|l|}{ BMI $\left(\mathrm{kg} / \mathrm{m}^{2}\right), 2000$} \\
\hline$<30$ & 1232 & $80 \cdot 8$ & 1482 & $80 \cdot 1$ & \\
\hline$\geq 30$ & 293 & $19 \cdot 2$ & 369 & 19.9 & \\
\hline \multicolumn{6}{|l|}{ Self-assessed health, 2000} \\
\hline Good & 1066 & 69.9 & 1381 & $74 \cdot 6$ & \\
\hline Poor & 460 & $30 \cdot 1$ & 471 & 25.4 & $<0.05$ \\
\hline \multicolumn{6}{|l|}{ Diabetes, 2000} \\
\hline No & 1477 & $96 \cdot 7$ & 1803 & $97 \cdot 3$ & \\
\hline Yes & 50 & 3.3 & 50 & $2 \cdot 7$ & \\
\hline \multicolumn{6}{|l|}{ CVD, 2000} \\
\hline No & 968 & 63.4 & 1229 & 66.5 & \\
\hline Yes & 558 & $36 \cdot 6$ & 619 & 33.5 & \\
\hline \multicolumn{6}{|l|}{ Vegetables, 2000} \\
\hline $5 \mathrm{~d} /$ week or less & 704 & $46 \cdot 1$ & 623 & 33.6 & \\
\hline $6-7 \mathrm{~d} /$ week & 824 & $53 \cdot 9$ & 1230 & 66.4 & $<0.001$ \\
\hline \multicolumn{6}{|l|}{ Rye bread, 2000} \\
\hline 0-5 slices/d & 1135 & 74.5 & 1575 & 85.4 & \\
\hline$>5$ slices $/ d$ & 388 & $25 \cdot 5$ & 270 & $14 \cdot 6$ & \\
\hline \multicolumn{6}{|l|}{ Bread spread, 2000} \\
\hline Nothing & 254 & $16 \cdot 6$ & 341 & 18.4 & \\
\hline Margarine & 900 & 58.9 & 1087 & $58 \cdot 7$ & \\
\hline Butter-vegetable oil mixture & 270 & $17 \cdot 7$ & 330 & $17 \cdot 8$ & \\
\hline Butter & 105 & 6.9 & 95 & $5 \cdot 1$ & $<0.05$ \\
\hline Bread spread, 2011 & & & & & \\
\hline Nothing & 130 & 8.5 & 147 & 7.9 & \\
\hline Margarine & 935 & $61 \cdot 2$ & 1104 & $59 \cdot 6$ & \\
\hline Butter-vegetable oil mixture & 334 & 21.8 & 495 & $26 \cdot 7$ & $<0.001$ \\
\hline Butter & 130 & 8.5 & 107 & $5 \cdot 8$ & $<0.01$ \\
\hline
\end{tabular}

${ }^{*}$ Participants with information on bread spreads in 2000 and 2011 ( $n$ 3382).

†Unadjusted $P$ values for the differences between men and women.

yourself physically in your leisure time?' Response alternatives were: (i) mainly reading, watching television or other activities that do not strain physically; (ii) mainly walking, cycling or moving in other ways for at least $4 \mathrm{~h} /$ week; (iii) vigorous activity for more than $3 \mathrm{~h} /$ week; and (iv) regular participation in competitive sports. In the analyses the variable was categorized into 'passive' (response i) and 'active' (responses ii-iv). Based on current smoking at the time of the interview the respondents were grouped into daily smokers and non-smokers (including occasional smokers). Alcohol consumption index originates from six questions on the quantity and frequency of alcoholic beverages consumed per week. Three usual beverage types (mild, wines, spirits) 
Table 2 Use ( $n$, row \%, column \%) of bread spreads in 2000 and 2011 among Finnish men and women participating in the Health 2000 and Health 2011 surveys

\begin{tabular}{|c|c|c|c|c|c|c|c|c|c|}
\hline \multirow[b]{3}{*}{ Bread spread, 2000} & \multicolumn{9}{|c|}{ Bread spread, 2011} \\
\hline & \multicolumn{3}{|c|}{ Margarine $^{\star}$} & \multicolumn{3}{|c|}{ Butter† } & \multicolumn{3}{|c|}{ Total } \\
\hline & $n$ & Row \% & Column \% & $n$ & Row \% & Column \% & $n$ & Row \% & Column \% \\
\hline \multicolumn{10}{|l|}{ Men } \\
\hline Margarine* & 882 & $76 \cdot 3$ & $82 \cdot 7$ & 272 & 23.7 & $58 \cdot 2$ & 1154 & $100 \cdot 0$ & $75 \cdot 2$ \\
\hline Buttert & 183 & 48.4 & $17 \cdot 3$ & 192 & 51.6 & 41.8 & 375 & $100 \cdot 0$ & $24 \cdot 8$ \\
\hline Total & 1065 & 69.4 & $100 \cdot 0$ & 464 & $30 \cdot 6$ & $100 \cdot 0$ & 1529 & $\begin{array}{c}100.0 \\
P<0.001 \ddagger\end{array}$ & $100 \cdot 0$ \\
\hline \multicolumn{10}{|l|}{ Women } \\
\hline Margarine* & 1064 & $74 \cdot 7$ & $85 \cdot 1$ & 364 & $25 \cdot 3$ & $60 \cdot 4$ & 1428 & $100 \cdot 0$ & $77 \cdot 1$ \\
\hline Butter† & 187 & $44 \cdot 2$ & 14.9 & 238 & $55 \cdot 8$ & 39.6 & 425 & $100 \cdot 0$ & 22.9 \\
\hline Total & 1251 & $67 \cdot 7$ & $100 \cdot 0$ & 602 & $32 \cdot 3$ & $100 \cdot 0$ & 1853 & $\begin{array}{c}100.0 \\
P<0.001 \ddagger\end{array}$ & $100 \cdot 0$ \\
\hline
\end{tabular}

${ }^{*}$ Margarine $=$ soft margarines and no spread on bread.

†Butter = butter and butter-vegetable oil mixture.

$\ddagger$ Test of marginal homogeneity of 2000 and 2011 bread spread distributions.

were included and the quantities were estimated as Finnish standard units (12 g of pure alcohol). The index was transformed into grams per day and divided into gender-specific tertiles (men 0, 32 and $130 \mathrm{~g} / \mathrm{d}$; women 0 , 7 and $36 \mathrm{~g} / \mathrm{d}$ ). The consumption of vegetables asked in the interview referred to the frequency of consumption during the previous week. The original four categories were combined into two: those who used vegetables daily (6-7 $\mathrm{d} /$ week) and those who did not ( $5 \mathrm{~d}$ /week or less). The number of slices of rye bread consumed daily was asked with an open question. The final variable included two categories, consumption of $>5$ slices/d and $0-5$ slices $/ \mathrm{d}$.

BMI was calculated from measured height and weight and was classified according to the WHO guidelines as obese $\left(B M I \geq 30 \mathrm{~kg} / \mathrm{m}^{2}\right)$ and not obese $\left(B M I<30 \mathrm{~kg} / \mathrm{m}^{2}\right)$. Self-assessed health was asked in the interview using five answering categories that were dichotomized as 'good' (good and reasonably good) and as 'poor' (average, rather poor, poor). In addition, the respondents were asked whether they had diabetes or any cardiovascular symptoms/diseases (CVD) as diagnosed by a doctor. The measure on CVD included questions concerning hypertension (prevalence among men $26 \%$, women $23 \%$ ), heart infarction, CHD, heart insufficiency, cardiac arrhythmia and other heart disease.

\section{Statistical analyses}

The sampling design was accounted for in analyses using methods based on linearization ${ }^{(31)}$ and the non-response using post-stratification weighting ${ }^{(28)}$ and inverse probability weighting ${ }^{(32)}$. Statistical analyses were conducted with the statistical software package STATA version 11.2.

Possible bias caused by non-response was examined by comparing the baseline sociodemographic, behavioural and health-related characteristics of participants who answered the question on bread spreads in 2011 with those of individuals who did not respond (see online supplementary material, Supplemental Table 1). The baseline consumption of butter-containing fats $v$. other fats was not associated with non-response to the question on bread spreads in the follow-up. Therefore, drop-out was not selective in regard to the outcome variable. When it comes to the predictor variables, non-response was selective. Men and women living without a spouse, having a lower educational level, being non-employed, smoking, being physically inactive, obese and having poor health participated in the follow-up less often. In regard to alcohol consumption at baseline both men and women who belonged to the medium tertile of consumption participated more often. Infrequent use of vegetables predicted non-response but only among men (Supplemental Table 1).

The prevalence of predictor variables at baseline and the prevalence of different types of bread spreads in 2000 and 2011 were examined (Table 1). In addition, we examined the associations between baseline predictor variables and the use of butter-containing spreads $v$. others in 2011. The statistical significance of the associations was estimated with the $\chi^{2}$ independence test separately for men and women. These analyses showed associations with educational level, place of residence, health-related variables and the use of bread spreads in 2011 (data not shown).

To estimate the prevalence of all types of change in the consumption of bread spreads during the follow-up we checked the proportions of persons who (i) maintained their baseline habits and (ii) shifted from butter-containing fat to margarine/no fat on bread (Table 2).

Statistical modelling was conducted sequentially in order to examine the predictors of the shift from margarine/no fat on bread to butter-containing fats during the follow-up. The logistic regression analyses included only those who did not use butter at baseline ( $n$ 2582, Table 2 ). 
Relative risks (RR) and $95 \%$ confidence intervals were estimated for the change from margarine to butter. Previous studies suggested that gender is associated with many sociodemographic and dietary factors. Therefore, we tested all predictor-gender interactions before the final modelling procedure. The tests showed two significant interactions: gender-education and gender-marital status. In addition, the interaction between gender and age was near statistical significance. Since the numbers of cases were too small to carry out all analyses stratified by gender, separate male and female factors were included in the model only in regard to education, marital status and age.

As a first step, the sociodemographic factors were included in the model. Second, health behaviours were also included. Third, BMI, self-assessed health, diabetes and CVD were included in the model with sociodemographic factors and health-related behaviours. A goodness-of-fit test (Hosmer-Lemeshow) was conducted for the final, fully adjusted model.

\section{Results}

\section{Changes in bread spread among men and women between 2000 and 2011}

At baseline $16.6 \%$ of men did not have spread on their bread compared with $8.5 \%$ at follow-up. Among women the corresponding figures were $18.4 \%$ and $7.9 \%$. The proportion of respondents having margarine on bread was about $60 \%$ at both baseline and follow-up (Table 1).

Of the 2582 respondents who did not use butter-containing spreads at baseline $24.6 \%$ shifted to them, while the majority of those who used margarine or had no spread on bread maintained their habit. There were shifts in the opposite direction, as well. Altogether $46.3 \%$ (men $48.4 \%$, women $44.2 \%$ ) of the 800 baseline butter users shifted to margarine or gave up using any spread during the follow-up (Table 2).

The increase in the proportion of butter users between 2000 and 2011 was larger among women than men. At baseline $22.9 \%$ of women used butter on bread compared with $32.3 \%$ at follow-up. Among men the corresponding figures were $24.8 \%$ and $30 \cdot 6 \%$ (Table 2 ).

\section{Predictors of change from margarine to butter between 2000 and 2011}

According to the multivariate models gender had a significant interaction with age $(P=0.035)$, educational level $(P=0.068)$ and marital status $(P=0.034$; data not shown). To demonstrate how gender, age, education and marital status interacted with each other, the relative risks of changing from margarine/no fat on bread to butter were analysed for men and women separately and including only age, education and marital status in the univariate models (Table 3). Women belonging to the younger age group in 2000 (30-44 years) were more likely to shift from other spreads to butter-containing fats than the other women. Among men, age group did not predict the change of bread spreads, whereas those who had lower educational level and those who were living with a spouse more often shifted to butter than the other men.

The strength and direction of the effects of the baseline predictors on the shift from margarine/no fat on bread to butter are presented in Table 4.

Being female predicted clearly the change of bread spread, as the proportion of women who changed from margarine/no fat on bread to butter was significantly higher than that of men, even after adjusting for baseline health behaviours and health/illness $(\mathrm{RR}=2 \cdot 47,95 \% \mathrm{CI}$ 1.44, 4.26; Table 4, model 3). Age did not predict the shift from margarine/no fat on bread to butter among men (Table 4). Women who belonged to the younger age group of 30-44 years in 2000 shifted more often from other spreads to butter than the older women, but the relative risk was no longer significant $(\mathrm{RR}=0 \cdot 81,95 \% \mathrm{CI}$ $0.63,1.04$ ) in the multinomial model (Table 4 , models 1 and 2) as it was in the univariate model (Table 3).

Educational level predicted the change of bread spread among men, but the effect of education was attenuated after adjusting for health behaviours. Men with the lowest

Table 3 Relative risk of changing from margarine/no spread to butter-containing spreads among Finnish men and women participating in the Health 2000 and Health 2011 surveys by age, education and marital status: univariate models ( $n$ 1154)

\begin{tabular}{|c|c|c|c|c|}
\hline & \multicolumn{2}{|c|}{ Men } & \multicolumn{2}{|c|}{ Women } \\
\hline & $\mathrm{RR}$ & $95 \% \mathrm{Cl}$ & $\mathrm{RR}$ & $95 \% \mathrm{Cl}$ \\
\hline \multicolumn{5}{|c|}{ Age (years), 2000} \\
\hline $30-44$ & 1.00 & Ref. & 1.00 & Ref. \\
\hline $45-64$ & 1.17 & $0.89,1.55$ & 0.79 & $0.62,1.00$ \\
\hline \multicolumn{5}{|l|}{ Education, 2000} \\
\hline Highest & 1.00 & Ref. & 1.00 & Ref. \\
\hline Intermediate & $1 \cdot 19$ & $0.85,1.65$ & 0.87 & $0.66,1.16$ \\
\hline Lowest & 1.46 & $1 \cdot 01,2 \cdot 11$ & 0.84 & $0.62,1.13$ \\
\hline \multicolumn{5}{|c|}{ Marital status, 2000} \\
\hline No spouse & 1.00 & Ref. & 1.00 & Ref. \\
\hline Spouse & 1.64 & $1 \cdot 14,2 \cdot 37$ & 0.99 & $0.75,1.32$ \\
\hline
\end{tabular}

$\mathrm{RR}$, relative risk; Ref., reference category. 
Table 4 Predictors of the shift from margarine/no spread to butter-containing spreads between 2000 and 2011 among Finnish men and women participating in the Health 2000 and Health 2011 surveys: multinomial regression analysis, significant gender-related interactions included

\begin{tabular}{|c|c|c|c|c|c|c|}
\hline \multirow[b]{2}{*}{ Baseline, 2000} & \multicolumn{2}{|c|}{$\begin{array}{c}\text { Model 1: gender, age, background (1) } \\
\text { ( } n \text { 2582) }\end{array}$} & \multicolumn{2}{|c|}{$\begin{array}{l}\text { Model 2: model } 1+\text { health behaviours (2) } \\
\text { ( } n \text { 2532) }\end{array}$} & \multicolumn{2}{|c|}{$\begin{array}{c}\text { Model 3: model } 2+\text { health/illness (3) } \\
\text { ( } n \text { 2527) }\end{array}$} \\
\hline & $\mathrm{RR}$ & $95 \% \mathrm{Cl}$ & $\mathrm{RR}$ & $95 \% \mathrm{Cl}$ & $\mathrm{RR}$ & $95 \% \mathrm{Cl}$ \\
\hline \multicolumn{7}{|l|}{ Gender } \\
\hline Men & 1.00 & Ref. & 1.00 & Ref. & 1.00 & Ref. \\
\hline Women & 2.60 & $1.52,4.44$ & 2.53 & $1.47,4.35$ & 2.47 & $1.44,4.26$ \\
\hline \multicolumn{7}{|l|}{ Men: age (years) } \\
\hline $30-44$ & 1.00 & Ref. & 1.00 & Ref. & 1.00 & Ref. \\
\hline $45-64$ & $1 \cdot 10$ & $0.82,1.47$ & 1.09 & $0.81,1.47$ & $1 \cdot 13$ & $0.84,1.53$ \\
\hline \multicolumn{7}{|c|}{ Women: age (years) } \\
\hline $30-44$ & 1.00 & Ref. & 1.00 & Ref. & 1.00 & Ref. \\
\hline $45-64$ & 0.81 & $0.63,1.04$ & 0.81 & $0.63,1.05$ & 0.84 & $0.65,1.09$ \\
\hline \multicolumn{7}{|l|}{ Men: education (1) } \\
\hline Highest & 1.00 & Ref. & 1.00 & Ref. & 1.00 & Ref. \\
\hline Intermediate & 1.20 & $0.86,1.68$ & $1 \cdot 16$ & $0.83,1.63$ & $1 \cdot 16$ & $0.82,1.63$ \\
\hline Lowest & 1.49 & $1.01,2 \cdot 18$ & 1.38 & $0.93,2.05$ & 1.39 & $0.94,2.07$ \\
\hline \multicolumn{7}{|c|}{ Women: education (1) } \\
\hline Highest & 1.00 & Ref. & 1.00 & Ref. & 1.00 & Ref. \\
\hline Intermediate & 0.89 & $0.67,1.17$ & 0.88 & $0.66,1.17$ & 0.89 & $0.67,1.18$ \\
\hline Lowest & 0.92 & $0.67,1.26$ & 0.89 & $0.64,1.23$ & 0.90 & $0.65,1.25$ \\
\hline \multicolumn{7}{|l|}{ Population size (1) } \\
\hline$<100000$ & 1.00 & Ref. & 1.00 & Ref. & 1.00 & Ref. \\
\hline$\geq 100000$ & 0.82 & $0.67,1.00$ & 0.83 & $0.67,1.02$ & 0.83 & $0.67,1.02$ \\
\hline \multicolumn{7}{|c|}{ Men: marital status (1) } \\
\hline No spouse & 1.00 & Ref. & 1.00 & Ref. & 1.00 & Ref. \\
\hline Spouse & 1.67 & $1.14,2.42$ & 1.61 & $1.09,2.37$ & 1.61 & $1.09,2.38$ \\
\hline \multicolumn{7}{|c|}{ Women: marital status (1) } \\
\hline No spouse & 1.00 & Ref. & 1.00 & Ref. & 1.00 & Ref. \\
\hline Spouse & 0.96 & $0.72,1.27$ & 0.94 & $0.70,1.25$ & 0.94 & $0.70,1.25$ \\
\hline \multicolumn{7}{|c|}{ Economic activity (1) } \\
\hline Non-employed & 1.00 & Ref. & 1.00 & Ref. & 1.00 & Ref. \\
\hline Employed & 1.18 & $0.95,1.48$ & 1.16 & $0.93,1.46$ & 1.13 & $0.89,1.42$ \\
\hline \multicolumn{7}{|l|}{ Alcohol (2) } \\
\hline Lowest & & & 1.00 & Ref. & 1.00 & Ref. \\
\hline Medium & & & 1.06 & $0.83,1.35$ & 1.06 & $0.83,1.35$ \\
\hline Highest & & & 1.00 & $0.79,1.26$ & 1.00 & $0.79,1.26$ \\
\hline \multicolumn{7}{|l|}{ Smoking (2) } \\
\hline No & & & 1.00 & Ref. & 1.00 & Ref. \\
\hline Yes, daily & & & $1 \cdot 12$ & $0.88,1.43$ & 1.13 & $0.89,1.44$ \\
\hline \multicolumn{7}{|l|}{ Physical activity (2) } \\
\hline Yes & & & 1.00 & Ref. & 1.00 & Ref. \\
\hline No & & & 1.01 & $0.80,1.26$ & 1.00 & $0.79,1.25$ \\
\hline Roots and vegetak & les (2) & & & & & \\
\hline $5 \mathrm{~d} /$ week or less & & & 1.00 & Ref. & 1.00 & Ref. \\
\hline $6-7 \mathrm{~d} /$ week & & & 1.06 & $0.87,1.28$ & 1.06 & $0.87,1.28$ \\
\hline Rye bread (2) & & & & & & \\
\hline 0-5 slices/d & & & 1.00 & Ref. & 1.00 & Ref. \\
\hline$>5$ slices $/ \mathrm{d}$ & & & 0.97 & $0.76,1.22$ & 0.97 & $0.76,1.22$ \\
\hline BMI $\left(\mathrm{kg} / \mathrm{m}^{2}\right)(3)$ & & & & & & \\
\hline$<30$ & & & & & 1.00 & Ref. \\
\hline$\geq 30$ & & & & & $1 \cdot 17$ & $0.93,1.48$ \\
\hline Self-assessed hea & th (3) & & & & & \\
\hline Good & & & & & 1.00 & Ref. \\
\hline Poor & & & & & 0.91 & $0.72,1.14$ \\
\hline Diabetes (3) & & & & & & \\
\hline No & & & & & 1.00 & Ref. \\
\hline Yes & & & & & 1.07 & $0.64,1.78$ \\
\hline CVD (3) & & & & & & \\
\hline No & & & & & 1.00 & Ref. \\
\hline Yes & & & & & 0.83 & $0.68,1.02$ \\
\hline
\end{tabular}

RR, relative risk; Ref., reference category.

Significant results are indicated in bold font. 
education ( $\mathrm{RR}=1.49$, 95\% CI $1.01,2 \cdot 18)$ more likely changed to butter. Among women educational level did not predict the shift in bread spread. Respondents living in larger cities were less likely to change margarine/no spread to butter-containing spreads. Marital status predicted the fat choices among men but not among women. Men who lived with a spouse $(\mathrm{RR}=1 \cdot 67,95 \%$ CI $1 \cdot 14$, $2 \cdot 42)$ were more likely to change to butter than single men (Table 4, model 1).

Health behaviours, BMI, self-assessed health, diabetes and CVD did not predict the shift to butter-containing fats. Moreover, the effect of spouse diminished somewhat when adjusting for health behaviours and the effect of place of residence was attenuated when adjusting for health behaviours (Table 4, model 2).

The goodness-of-fit test (Hosmer-Lemeshow, $n$ 2527, $\left.\mathrm{df}=10, \chi^{2}=6.61\right)$ showed a value of $P=0.762$ for the fully adjusted model (Table 4 , model 3 ). Thus, the model fitted the data well.

\section{Discussion}

The present 11-year longitudinal study examined the predictors of changes in the use of bread spreads among Finns aged 30-64 years. The study focused on the shift from having margarine/no spread on bread (referred to as 'margarine') to butter/butter-vegetable oil mixture (referred to as 'butter'). Only a few of the baseline sociodemographic determinants predicted the change. We found that:

1. Finnish women were more likely to change from margarine to butter than men;

2. the predictive effect of age and marital status depended on gender - younger women changed to butter more often than the older age group and men changed to butter-containing spreads more often when they were living with a spouse;

3. high educational level did not predict the shift from margarine to butter; and

4. among men low educational level predicted the change to butter but the effect was attenuated when adjusting for health behaviours.

To our knowledge, comparable longitudinal studies on sociodemographic determinants of recent changes in the consumption of bread spreads have not been conducted. In line with our results, an overall increase in the intake of saturated fat has been observed in an Australian and a North American $^{(33,34)}$ longitudinal population study. The intake of saturated fat increased among Australian women but decreased among men from 1992/94 to 2002/04. The participants were 49 years and over at baseline ${ }^{(33)}$. In the Framingham Offspring cohort study among men and women aged at least 25 years in 1991, the percentage of energy from total fat increased between 1991 and 2008 among both genders, but women showed a greater increase in the percentage of energy from saturated fat ${ }^{(34)}$. International cohort studies completed before the turn of the century seem to point in the opposite direction ${ }^{(35-37)}$.

Previous theoretical approaches ${ }^{(20,21)}$, international comparisons $^{(22)}$ and Finnish cross-sectional studies ${ }^{(24,25,38,39)}$ have suggested that gender and socio-economic status are associated with dietary changes. The present study supports the assumption regarding women as nutritional gatekeepers and pioneers of dietary changes. The role of women was also demonstrated by our observation that men more often shifted to butter if they had a spouse.

In the 1990s, butter was classified as a traditional food $^{(24,40)}$. The fact that younger women shifted from margarine to butter may be related to the availability of soft vegetable margarines in Finland. Younger women had the chance to eat margarine in childhood, so for them margarine may be traditional and butter modern. For the older generation born before 1960, butter is the traditional fat, since soft margarines were not available in their childhood.

A recent Finnish study that applied Bourdieu's theory ${ }^{(21,41,42)}$ presented heavy and simple foods - rye bread, porridge, potato, pork, beef, (fried) fish and milk products as examples of traditional culture. The study assumed that the dominant trend in Finnish food culture is the change from traditional foods to lighter and more global foods. According to the study, younger women with high education more often had a positive attitude towards new and light foods.

Our results do not support the assumptions that we made on the basis of earlier studies. For example, one of our assumptions was that women and higher educational groups - the most health-conscious groups - would be less likely to shift from margarine to butter. In contrast to the assumption, our results showed that women were more likely to shift to butter, while no association was found for high education and the shift to butter. Among men, low educational level predicted the shift to butter, but the effect was attenuated after adjusting for health behaviours. Furthermore, our study leaves open the question as to why men and women in less urbanized areas changed from margarine/no fat on bread to butter, from the 'healthier and lighter' alternatives to the less healthy. Obviously health is just one of the motives associated with food choice. A Finnish study ${ }^{(39)}$ on food choice motives and their role in the consumption of fruits/vegetables and energy-dense foods showed that health and pleasure were rated as the most important motives, followed by price, convenience, ethicality and familiarity. Women placed more importance on health while men scored higher on familiarity. Individual priorities in food choice motives varied by educational level and played a role in food choice. Participants with a low level of education placed more importance on familiarity and ate more energy-dense foods.

Our results might reflect the confusing and lively public discussion on the health effects of dietary fats in Finland at the time of the follow-up. The discussion probably distorted earlier gender- and class-related distinctions in regard to foods. In 2011, the mass media was provoked by the sharp 
increase in butter demand and linked it to the ongoing debate about saturated fats and carbohydrates. A recent Finnish study $^{(43)}$ explored the debate about the health effects of saturated fats and carbohydrates between followers of 'low-carb' diets and those agreeing with the current dietary recommendations. Content analysis of online discussions revealed two discourses that criticized the recommendation to avoid saturated fats. The first discourse was based on individual experiences of the positive health effects of a lowcarb diet. The commentators expected new studies and recommendations that take into account the positive personal experiences of the followers of a low-carb diet. The second discourse criticized directly the scientific background of the recommendations and doubted the economic and political interests of nutrition experts. The two discourses revealed a strong interest in health and healthy diet despite the distrust regarding recommendations. The participants of the debate seemed to be more health-conscious than average Finns and were also motivated to follow a healthy lifestyle.

\section{Methodological considerations}

When interpreting the results, limitations concerning non-response and measures of the use of bread spreads need to be taken into account. At follow-up, the response rate was lower (62\%) than at baseline (86 \%). As could be expected, the drop-out was somewhat selective. Men and women living without a spouse, having a lower educational level, being non-employed, smoking, being physically inactive, obese and having poor health were over-represented among the non-respondents at follow-up. Fortunately, however, the drop-out was not selective in regard to the baseline measurement of bread spreads.

During an 11-year follow-up, one can expect changes not only in the use of bread spreads but also in the predictor variables, such as place of residence, employment or marital status, health and health behaviour. Even if we had taken into account data on predictors at follow-up, we would not be able to detect whether changes in predictors preceded the changes in the use of bread spreads, or took place after the change of spread. The study design of two data collection points probably dilutes the effects of the predictors.

The variable on the use of bread spreads allowed only for binary classifications of the respondents into users and non-users. To maintain statistical power we combined butter and butter-vegetable oil mixture. These two spreads may have different user profiles even if they both are classified as non-recommended in Finnish dietary guidelines.

Despite the limitations our results on the overall changes in the use of bread spreads are in line with consumption statistics and repeated cross-sectional studies ${ }^{(9,44)}$. There is evidence that the choice between butter and margarine is associated with other fat consumption habits. The latest Finnish dietary survey shows that butter and butter-vegetable oil mixtures are important sources of saturated fats ${ }^{(12,45)}$ and comparisons of the question regarding bread spreads with more detailed food intake measures and serum cholesterol levels suggest that the question used in the current study is a relatively robust indicator of the intake of saturated fat ${ }^{(46,47)}$. Limitations regarding drop-out and the measure of fat intake together with the long follow-up time and only two measurement points may have reduced the opportunities to observe statistically significant results.

\section{Conclusions}

Female gender was the strongest predictor of the change from margarine/no fat on bread to butter/butter-vegetable oil mixtures between 2000 and 2011. Only a few of the studied baseline sociodemographic factors predicted the change and generally the results did not correspond with earlier assumptions on determinants of dietary changes. The change from margarine to butter was more than a matter of compliance with the official recommendation to prefer vegetable fats over butter. Further longitudinal studies on social and behavioural predictors of dietary changes are needed to understand differences in the effects of time, age and cohort in population studies. Identification of pioneer groups of dietary changes is decisive in the development of effective food and nutrition policies. First, the predictors of different types of consumption changes - fruit and vegetables, bread, high-fat milk, meat, total fat - should be examined. Moreover the changes should be analysed together with the motives of food choice.

\section{Acknowledgements}

Financial support: This research received no specific grant from any funding agency in the public, commercial or not-for-profit-sectors. Conflict of interest: None. Authorship: All authors contributed to the formulation of the research questions, study design and interpretation of the empirical results. R.P. wrote the first draft and every author commented and corrected the manuscript versions. E.L. carried out the statistical analyses and planned them together with T.M.-O. T.M.-O. coordinated the data collection in 2011. Ethics of buman subject participation: This study was conducted according to the guidelines laid down in the Declaration of Helsinki. The Coordinating Ethics Committee of Helsinki and Uusimaa hospital district (HUS) approved the Health 2000 and Health 2011 protocols. All participants received information on the study and provided their written informed consent.

\section{Supplementary material}

To view supplementary material for this article, please visit http://dx.doi.org/10.1017/S1368980015003390 


\section{References}

1. Borodulin K, Vartiainen E, Peltonen M et al. (2014) Forty-year trends in cardiovascular risk factors in Finland. Eur J Public Health 25, 539-546.

2. Vartiainen E, Laatikainen T, Peltonen M et al. (2010) Thirty-five-year trends in cardiovascular risk factors in Finland. Int J Epidemiol 39, 504-518.

3. Valsta LM, Tapanainen H, Sundvall J et al. (2010) Explaining the 25-year decline of serum cholesterol by dietary changes and use of lipid-lowering medication in Finland. Public Health Nutr 13, 932-938.

4. Männistö S, Laatikainen T, Helakorpi S et al. (2010) Monitoring diet and diet-related chronic disease risk factors in Finland. Public Health Nutr 13, 907-914.

5. Puska P (1978) Suomalaisen aikuisväestön terveyskäyttäytyminen, kevät 1978 (Health Behaviour among Finnish Adult Population, Spring 1978). Helsinki: Kansanterveyslaboratorio.

6. Helakorpi S, Uutela A, Prättälä R et al. (2000) Health Behaviour and Health Among the Finnish Adult Population, Spring 2012. Report B8/2000. Helsinki: National Institute for Health and Welfare.

7. Puska P, Salonen JT, Nissinen A et al. (1983) Change in risk factors for coronary heart disease during 10 years of a community intervention programme (North Karelia project). Br Med J (Clin Res Ed) 287, 1840-1844.

8. Pietinen P, Lahti-Koski M, Vartiainen E et al. (2001) Nutrition and cardiovascular disease in Finland since the early 1970s: a success story. J Nutr Health Aging 5, 150-154.

9. Food and Agriculture Organization of the United Nations (2014) Balance sheet for food commodities. http://185.20.137.77/en/balance-sheet-food-commodities-2013preliminary-and-2012-final-figures_en (accessed March 2015).

10. Männistö S, Lundqvist A, Prättälä R et al. (2012) Ruokatottumukset (Food habits). In Terveys, toimintakyky ja byvinvointi Suomessa 2011 (Health, Functional Capacity and Welfare in Finland 2011). Report 68/2012, pp. 51-54 [S Koskinen, A Lundqvist and $\mathrm{N}$ Ristiluoma, editors]. Helsinki: National Institute for Health and Welfare.

11. Vartiainen E, Borodulin K, Sundvall J et al. (2012) Finriski-tutkimus: Väestön kolesterolitaso on vuosikymmenen laskun jälkeen kääntynyt nousuun (Cholesterol levels in the Finnish population have increased after decades of decline). Suomen Lääkärilehti 67, 2364-2368.

12. Raulio S, Ovaskainen M, Tapanainen H et al. (2013) Ruokavalio on entistä rasvaisempi, kovan rasvan osuus kasvanut - Finravinto 2012 -tutkimuksen tuloksia (The share of fat and saturated fat in the diet has increased - results from the Findiet 2012 study). Tutkimuksesta tivivisti 4, October 2013. Helsinki: National Institute for Health and Welfare.

13. Raulio S, Ovaskainen M, Laatikainen $T$ et al. (2014) Tyydyttyneen rasvan saanti suomalaisilla aikuisilla: Finravinto 2012 -tutkimus (Intake of saturated fats among Finnish adults: Findiet 2012 study). Tutkimuksesta tiivisti 11, April 2014. Helsinki: National Institute for Health and Welfare.

14. Food and Agriculture Organization of the United Nations (2015) Food Balance Sheets. http://faostat3.fao.org/ (accessed August 2015).

15. Steingrimsdottir L, Valgeirsdottir H, Halldorsson TI et al. (2014) National nutrition surveys and dietary changes in Iceland. Economic differences in healthy eating. Laeknabladid 100, 659-664.

16. Johansson I, Nilsson LM, Stegmayr B et al. (2012) Associations among 25-year trends in diet, cholesterol and BMI from 140,000 observations in men and women in Northern Sweden. Nutr J 11, 40.

17. Vartiainen E, Laatikainen T, Tapanainen H et al. (2014) Vähähilihydraattinen ruokavalio ja veren kolesteroli (Low-carbohydrate diet and serum cholesterol). Tutkimuksesta tiiviisti 1, January 2014. Helsinki: National Institute for Health and Welfare.
18. Grosse Frie K \& Janssen C (2009) Social inequality, lifestyles and health - a non-linear canonical correlation analysis based on the approach of Pierre Bourdieu. Int J Public Health 54, 213-221.

19. Smith-Ray RL, Almeida FA, Bajaj J et al. (2009) Translating efficacious behavioral principles for diabetes prevention into practice. Health Promot Pract 10, 58-66.

20. Rogers E (2002) Diffusion of preventive innovations. Addict Behav 27, 989-992.

21. Bourdieu P (1984) Distinction: A Social Critique of the Judgement of Taste. Cambridge, MA: Harvard University Press (originally published in France 1979).

22. Wardle J, Haase AM, Steptoe A et al. (2004) Gender differences in food choice: the contribution of health beliefs and dieting. Ann Behav Med 27, 107-116.

23. Koskinen S, Puska P \& Valkonen T (1981) Terveyskäyttäytyminen keski-ikäisen väestön osarybmissä 1978-1980 (Health Behaviour in Subgroups of Middle-Aged Population). Report B1/1981. Helsinki: Kansanterveyslaboratorio.

24. Roos E, Prattala R, Lahelma E et al. (1996) Modern and healthy? Socioeconomic differences in the quality of diet. Eur I Clin Nutr 50, 753-760.

25. Prättälä R, Berg MA \& Puska P (1992) Diminishing or increasing contrasts? Social class variation in Finnish food consumption patterns, 1979-1990. Eur J Clin Nutr 46, 279-287.

26. Laaksonen M, Prattala R \& Karisto A (2001) Patterns of unhealthy behaviour in Finland. Eur J Public Health 11, 294-300.

27. National Institute for Health and Welfare (2014) Health 2011: health examination study. http://www.terveys 2011. info/ (accessed March 2015).

28. Heistaro S (2008) Methodology report. Health 2000 survey. http://www.terveys2000.fi/ (accessed December 2014).

29. Koskinen S, Lundqvist A \& Ristiluoma N (editors) (2012) Terveys, toimintakyky ja byvinvointi Suomessa 2011 (Health Functional Capacity and Welfare in Finland in 2011). Report 68/2012. Helsinki: National Institute for Health and Welfare.

30. Paalanen L, Prattala R, Palosuo H et al. (2010) Socio-economic differences in the use of dairy fat in Russian and Finnish Karelia, 1994-2004. Int J Public Health 55, 325-337.

31. Lehtonen R \& Pahkinen E (2004) Practical Methods for Design and Analysis of Complex Surveys, 2nd ed. Chichester: John Wiley \& Sons.

32. Robins JM, Rotnitzky A \& Zhao LP (1994) Estimation of regression coefficients when some regressors are not always observed. I Am Stat Assoc 89, 846-866.

33. Flood VM, Burlutsky G, Webb KL et al. (2010) Food and nutrient consumption trends in older Australians: a 10-year cohort study. Eur J Clin Nutr 64, 603-613.

34. Vadiveloo M, Scott M, Quatromoni P et al. (2014) Trends in dietary fat and high-fat food intakes from 1991 to 2008 in the Framingham Heart Study participants. Br J Nutr 111, 724-734.

35. Kimokoti RW, Newby PK, Gona P et al. (2012) Stability of the Framingham Nutritional Risk Score and its component nutrients over 8 years: the Framingham Nutrition Studies. Eur J Clin Nutr 66, 336-344.

36. Osler M, Heitmann BL \& Schroll M (1997) Ten year trends in the dietary habits of Danish men and women. Cohort and cross-sectional data. Eur J Clin Nutr 51, 535-541.

37. Prynne CJ, Paul AA, Mishra GD et al. (2005) Changes in intake of key nutrients over 17 years during adult life of a British birth cohort. Br J Nutr 94, 368-376.

38. Roos E, Lahelma E, Virtanen M et al. (1998) Gender, socioeconomic status and family status as determinants of food behaviour. Soc Sci Med 46, 1519-1529.

39. Konttinen $\mathrm{H}$, Sarlio-Lahteenkorva S, Silventoinen $\mathrm{K}$ et al. (2013) Socio-economic disparities in the consumption of vegetables, fruit and energy-dense foods: the role of motive priorities. Public Health Nutr 16, 873-882. 
40. Maula J (1995) Changes in Finnish Food Consumption 1950-1993. Publication 10/1995. Helsinki: National Consumer Research Centre (in Finnish).

41. Purhonen S, Gronow J, Heikkilä R et al. (2014) Suomalainen maku. Kulttuuripääoma, kulutus ja elämäntyylien sosiaalinen eriytyminen (Finnish Taste). Helsinki: Gaudeamus.

42. Purhonen S \& Gronow J (2014) Polarizing appetites? Food Cult Soc 317, 27-47.

43. Jauho M (2013) Tiedevastaisuutta vai tiedekriittisyyttä? Vähähiilihydraattisen ruokavalion kannattajien käsityksiä asiantuntijuudesta ja tieteellisestä tiedosta (Anti-science or critical of science? Low carb diet advocates' views on expertise and scientific knowledge). Yhteiskuntapolitiikka 78, 365-377.
44. Helldán A, Helakorpi S, Virtanen S et al. (2013) Health Behaviour and Health among the Finnish Adult Population, Spring 2012. Report 15/2013. Helsinki: National Institute for Health and Welfare.

45. Helldán A, Raulio S, Kosola M et al. (2013) Finravinto 2012tutkimus (The National FINDIET 2012 Survey). Report 16/ 2013. Helsinki: National Institute for Health and Welfare.

46. Roos E, Ovaskainen ML \& Pietinen P (1995) Validity and comparison of three saturated fat indices. Scand J Nutr 39, 55-59.

47. Paalanen L (2012) Food habits and related biomarkers in Pitkäranta, Russia, and North Karelia, Finland. Trends and educational differences, 1992-2007. PhD Thesis, University of Helsinki. 